DOI: $\underline{10.35619 / \text { iiu.v1i13.343 }}$

Антоненко Наталія старший викладач кафедри практики англійської мови Рівненського державного гуманітарного університету,

м. Рівне, Україна

ORCID: 0000-0002-6313-5397

e-mail:antnatasha73@gmail.com

\title{
ВИКОРИСТАННЯ АВТЕНТИЧНИХ ЗАВДАНЬ НА ЗАНЯТТЯХ 3 АНГЛІЙСЬКОЇ МОВИ У ЗАКЛАДАХ ВИЩОЇ ОСВІТИ
}

Анотація. У статті досліджено роль автентичних завдань на заняттях з іноземної мови для студентів ЗВО. Визначено основні принципи та шляхи їх реалізації для різних видів мовленнєвої діяльності. Розглянуто автентичну діяльність як ефективний спосіб мінімізації несумісності між навчальною та реальною комунікативною ситуацією, що своєю чергою спричиняє значні перешкоди у використанні іноземної мови.

Викладачі іноземних мов визнають переваги застосування автентичних завдань у ЗВО, вважаючи їх доречними, цікавими та сучасними для студентів, які вивчають іноземну мову. Викладання іноземної мови $з$ використанням автентичних завдань - запорука підвищення мотивації студентів. Будучи вмотивованими, тривожність студентів зменшується, а впевненість зростає як під час участі у мовленнєвій діяльності, так і у процесі застосовування іноземної мови в реальних обставинах.

Розробка автентичних мовленнєвих завдань для студентів-філологів спрощується тим, що вони характеризуються широким спектром складних граматичних та лексичних структур. Високий рівень володіння іноземною мовою дозволяє широко застосовувати автентичні матеріали (друковані, відео- та аудіоматеріали), які носії мови використовують у своєму повсякденному житті. У статті аналізуються основні критерії автентичних завдань і їх типи.

Ключові слова: автентичні завдання, ситуації іншомовного спілкування, характеристики автентичних завдань, типи автентичних завдань, комунікативна компетенція.

Постановка проблеми. Євроінтеграційні та світоінтеграційні прагнення України вимагають підвищення рівня володіння іноземними мовами, зокрема англійською як домінуючої у сучасному світі мови міжнародного спілкування. 3 огляду на це зростає роль випускників закладів педагогічної освіти, які покликані забезпечити можливості країни у сфері готовності до міжнародної комунікації. Найголовнішою їхньою функцією $є$ популяризація іноземних мов шляхом їх якісне викладання. 


\section{Інноватика у вихованні. Випуск 13.Том 1. 2021.}

Отже, для якісного та кваліфікованого викладання іноземної мови необхідне виконання такої обов'язкової умови, як володіння цією мовою на високому професійному рівні.

Оволодіти основними формами усного і писемного спілкування, не перебуваючи в країні виучуваної мови досить складно. Тому одним із найважливіших завдань викладача $є$ створення реальних і уявних ситуацій спілкування на практичних заняттях з іноземної мови, з використанням різних автентичних матеріалів, які знайомлять студентів 3 культурними цінностями носія мови.

Мета статті - дослідити поняття «автентичне завдання», розглянути його типи та критерії.

Аналіз останніх досліджень 3 проблеми. Проблема використання автентичних завдань на уроках іноземної мови досліджувалася такими вченими, як М. Брін, Л. Ліер, Г. Ноейр, М. Морроу, Дж. Скрівенер, Д. Стаут та ін.

Проблему формування іншомовної комунікативної компетенції засобом використання автентичних матеріалів вивчали Г. Верещагін, О. Корчажкіна, Є. Носович, Р. Мільруд, Ю. Прохоров, В. Паращук, В. Редько, С. Роман та ін. (Северіна, 2020).

Виклад основного матеріалу дослідження. Максимальний розвиток комунікативних здібностей студентів - ось головне, i досить нелегке завдання, яке слід вирішити викладачам іноземних мов. На нашу думку, його вирішення можливе за умов застосування нових методів викладання, спрямованих на розвиток усіх чотирьох видів мовленнєвої діяльності (аудіювання, читання, говоріння, письма) і створення принципово нових навчальних матеріалів, за допомогою яких можна навчити студентів умінню спілкуватися.

Традиційні завдання часто не мають нічого спільного із ситуаціями реального життя. Як правило, вони вузько спрямовані щодо інформаційної наповнюваності та передбачають тільки одну правильну відповідь і лише один метод іiі отримання. У процесі розв'язання традиційного завдання відсутня внутрішня мотивація до його виконання, i, як наслідок, воно є нецікавим для студента. На противагу академічному підходу, автентичні завдання повторюють реальні життєві ситуації. Вони формують комунікативний досвід, який студенти можуть отримати за межами навчальної аудиторії, засобами іноземної мови. Такі завдання характеризуються ключовою формою розпізнавання та вирішення проблеми кількома методами іiі розв'язання, емоційним характером виконання та високою мотивацією. Саме тому автентичні завдання виходять за межі самого вивчення мови: студенти не просто практикують вживання нових слів чи граматичних структур, але й досягають певної мети, використовуючи іноземну мову.

Викладачі іноземних мов давно усвідомили переваги, які пропонують оригінальні автентичні завдання. Вони корисні для тих, хто вивчає іноземну мову, тому що є цікавими та актуальними. Введення у процес 


\section{Інноватика у вихованні. Випуск 13.Том 1. 2021.}

вивчення будь-якої іноземної мови автентичних завдань сприяє підвищенню мотивації студентів. Якщо вони вмотивовані, їхнє хвилювання зменшується, а впевненість зростає як під час занять в аудиторії, так і під час застосовування іноземної мови в реальних життєвих ситуаціях.

Викладачі повинні чітко розуміти зміст автентичних мовленнєвих завдань. Готуючись до заняття з використанням таких завдань, на нашу думку, педагог має скористатися порадами Д. Вілліс і Дж. Вілліс (2007) та дати відповіді на запитання і зрозуміти, чи ефективним буде розроблений ним дидактичний матеріал. Наведено приклади запитань:

Чи зацікавить складене вами завдання учнів?

Чи сконцентрована увага на змісті?

Яка мета та очікуваний результат завдання?

Чи оцінюється успішне виконання завдання з огляду на результат?

Чи є виконання завдання пріоритетним?

Чи має завдання зв'язок з реальними ситуаціями спілкування?

Дж. Херрингтон, Р. Олівер і Т. К. Рівз (2002) запропонували десять характеристик автентичних завдань, які можуть забезпечити необхідні умови для подолання бар'єру між навчальною аудиторією та реальним світом.

1. Автентичні завдання $€$ актуальними в реальних ситуаціях спілкування. Ситуація не штучно створюється, а береться 3 реального життя.

2. Автентичні завдання нечітко сформульовані та вимагають від студентів самостійного визначення задач і підзадач, необхідних для їхнього виконання. Проблеми, що розв’язуються, $\epsilon$ відкритими для численних інтерпретацій, а не дій за алгоритмом.

3. Автентичні завдання - складні завдання, які студенти будуть досліджувати протягом тривалого періоду часу. Діяльність може тривати дні, тижні та місяці, а не хвилини або години. Такі завдання вимагають залучення багатьох ресурсів та часу.

4. Автентичні завдання дають студентам можливість вивчати проблему 3 різних точок зору, використовуючи різноманітні ресурси. Завдання розглядаються з різних теоретичних та практичних перспектив, a не $з$ однієї, яку студентам потрібно наслідувати, щоб отримати оцінку. Для розв'язання необхідно використовувати різноманітні ресурси, а не обмежену кількість попередньо відібраних джерел.

5. Автентичні завдання створюють умови для співпраці. Співпраця $\epsilon$ невід'ємною частиною виконання завдання як у навчальному середовищі, так і в реальному житті.

6. Автентичні завдання забезпечують можливість для рефлексії. Вони стимулюють студентів розмірковувати та аналізувати свою діяльність як індивідуально, так і колективно.

7. Автентичні завдання можуть бути інтегровані та застосовані в різних предметних галузях і виходити за межі конкретних результатів. 


\section{Інноватика у вихованні. Випуск 13.Том 1. 2021.}

Вони мають міждисциплінарний зв'язок та дозволяють використовувати досвід у різноманітних галузях знань.

8. Оцінювання автентичних завдань $є$ невід'ємним від самого завдання. Воно оцінюється з огляду на значення для реального життя.

9. Автентичні завдання завершуються створенням певного продукту, який є цінним сам по собі, а не як тренування та підготовка до іншої діяльності.

10. Автентичні завдання допускають існування декількох варіантів розв'язання та різноманітності результатів.

Автентичні аспекти використання мови завдяки створенню цікавих, захоплюючих завдань, які легко вплітаються у навчальний контекст заняття розкрили у своїх наукових дослідженнях Х. Таттл (2007) і Д. Ріверс (2010).

Проаналізуємо деякі типи автентичних мовленнєвих завдань:

короткі відповіді на письмові/аудіовізуальні підказки: студенти отримують письмові чи аудіовізуальні підказки, на які вони усно відповідають спонтанно (без підготовки) або після обдумування відповіді, після чого викладач вислуховує кожну відповідь і аналізує тї;

складання розповідей: викладач демонструє зображення (малюнок, ілюстрацію, мультфільм тощо) та визначає тривалість часу, впродовж якого потрібно розглянути, наприклад, картину, і придумати розповідь. Після цього студенти розповідають оригінальні історії на основі зображення;

завершення історії: викладач створює звукову або аудіовізуальну підказку, аби передати мовою, що вивчається, початок та основну частину розповіді. Студенти повинні уважно слухати підказку, аби зрозуміти персонажів і основну сюжетну лінію. На завершення студентів просять придумати закінчення історії, використовуючи запропоновану лексику та граматику;

порівняння $i$ протиставлення: викладач створює аудіовізуальну підказку, використовуючи зображення або відео про реалії життя країни, мова якої вивчається (святкування, обряд, готування їжі, фото сім'ї тощо). Студенти уважно вивчають зображення чи відео та відшукують культурні відмінності з подіями власного життя. Після цього вони порівнюють те, що бачать, зі звичайними ситуаціями з власного досвіду, як-от обрядовість, сімейні відносини або кулінарні традиції;

парне рішення проблем: викладач створює аудіовізуальну підказку, в якій студентам дається завдання для розв'язання в парах. Наприклад: ви не встигли на літак у англомовній країні та маєте розробити стратегію поведінки у цій ситуації;

художня критика/аналіз: викладач створює візуальну підказку зображення відомої картини художника 3 англомовної країни. Учні описують те, що вони бачать на полотні. Наприклад, кольори та форми, обговорюють настрій, який картина може створити у спостерігача. Вони 


\section{Інноватика у вихованні. Випуск 13.Том 1. 2021.}

також розмірковують, чи подобається їм картина та чому. Зрештою, студенти пояснюють, що художник намагався передати через живопис;

nоточні подї: викладач створює аудіовізуальну підказку або підказку для читання, пропонуючи студентам проаналізувати актуальну подію. Студенти максимально детально описують свої погляди на цю тему.

Розробка автентичних мовленнєвих завдань для студентів-філологів, що спеціалізуються на вивченні іноземної мови, розширює можливості викладача завдяки тому, що студенти мають у своєму арсеналі складні лексичні та граматичні мовленнєві структури. Високий рівень мовленнєвої компетенції дозволяє викладачеві широко застосовувати у вправах різні види автентичних матеріалів (паперові, відео- та аудіоматеріали), які носії мови використовують у своєму повсякденному житті. Графічні, візуальні, візуально-слухові або слухові підказки можуть бути створені також із використанням новітніх технологічних інструментів навчання, таких як генератори QR-коду.

Висновки і перспективи подальших розвідок. Оскільки автентичні мовленнєві завдання підвищують мотивацію студентів і покращують їхній навчальний досвід, вони дають викладачу широкі можливості та роблять вивчення іноземних мов широкозмістовним. Саме тому подальшого вивчення потребує питання розробки класифікації автентичних завдань для розвитку різноманітних видів мовленнєвої діяльності на різних етапах вивчення іноземної мови. Тому вчителям іноземних мов варто розробляти та широко використовувати автентичні завдання відповідно до визначених критеріїв, застосовуючи освітні технології.

\section{СПИСОК ВИКОРИСТАНИХ ДЖЕРЕЛ}

Северіна, Т. (2020). Створення автентичного освітнього середовища у навчанні іншомовної граматики на різних етапах уроку в середній школі. Інноваційна педагогіка. Випуск 20, том 3, сс. 35-38 URL: http://www.innovpedagogy.od.ua/archives/2020/20/part_3/9.pdf [Дата звернення 02.02.21].

Willis, D. \& Willis, J. (2007). Doing task-based teaching. Oxford University Press, PP. 12-14.

Herrington, J., Oliver R. \& Reeves T. (2002). Patterns of Engagement in Authentic Online Learning Environments. Australian Journal of Educational Technology. Vol. 19. PP. 279-286.

Tuttle, H. (2007). Livening up foreign language: Technology enables language learning in authentic situations. Technology \& Learning. Vol. 28(4). PP. 40-42.

Rivers, D. (2010). An exploration of on-task language policy and student satisfaction. ELT Journal. Vol. 64(3). PP. 261-271. 


\title{
REFERENCES
}

Severina, T. (2020). Stvorennia avtentychnoho osvitnoho seredovyshcha u navchanni inshomovnoi hramatyky na riznykh etapakh uroku v serednii shkoli. Innovatsiina pedahohika [Innovative Pedagogy]. Vypusk 20, tom 3, s. 35-38. URL: http://www.innovpedagogy.od.ua/archives/2020/20/part_3/9.pdf [Data zvernennia 2 liutoho 2021] [in Ukrainian].

Willis, D. \& Willis, J. (2007) Doing task-based teaching. Oxford University Press, PP. 12-14.

Herrington, J., Oliver, R. \& Reeves, T. (2002) Patterns of Engagement in Authentic Online Learning Environments. Australian Journal of Educational Technology. Vol. 19. PP. 279-286.

Tuttle, H. (2007) Livening up foreign language: Technology enables language learning in authentic situations. Technology \& Learning. Vol. 28(4). PP. 40-42.

Rivers, D. (2010) An exploration of on-task language policy and student satisfaction. ELT Journal. Vol. 64(3). PP. 261-271.

\section{USE OF AUTHENTIC TASKS AT THE ENGLISH LESSONS IN HIGHER EDUCATION INSTITUTIONS}

\author{
Nataliia Antonenko \\ Lecturer at Practice of the English Language Department \\ Rivne State University for the Humanities, \\ Rivne, Ukraine \\ ORCID: 0000-0002-6313-5397 \\ e-mail: antnatasha73@gmail.com
}

\begin{abstract}
The article deals with the role of authentic activities in foreign language teaching for university students. The basic principles and ways of their implementation are also mentioned. Authentic activities are regarded as an effective way to narrow the gap between an instructional setting and real communicative situation. This gap provokes sufficient difficulties in using foreign language.

Foreign language teachers have long recognized the benefits authentic tasks offer. Authentic tasks are beneficial for foreign language learners because they find them engaging and more up-to-date. Enriching teaching and learning of any foreign language with authentic tasks leads to increased students' motivation. When students feel motivated, their anxiety reduces and confidence increases both while involved in class speaking activities and when they have to speak in the real-life situations.

Authentic tasks have several peculiarities. They have real world relevance; are ill-defined, requiring students to define the tasks and subtasks needed to complete the activity; comprise complex tasks to be investigated by students over a sustained period of time; provide the opportunity for students to examine the task from different perspectives, using a variety of resources; provide the
\end{abstract}




\section{Інноватика у вихованні. Випуск 13.Том 1. 2021.}

opportunity to collaborate; provide the opportunity to reflect; can be integrated and applied across different subject areas and lead beyond domain specific outcomes; are seamlessly integrated with assessment; create polished products valuable in their own right rather than as preparation for something else; allow competing solutions and diversity of outcome

As a result authentic speaking tasks make learning foreign languages meaningful, improve students' motivation and enhance their learning experience. Foreign language teachers should design authentic speaking tasks using a set of specific criteria and incorporating educational technology.

Keywords: authentic tasks, situations of foreign language communication, characteristics of authentic tasks, types of authentic tasks.

Стаття надійшла до редакиіï 10.04.2021p. 